\title{
Ruthenium-Catalyzed Synthesis of Quinolines from Anilines and Tris(3-hydroxypropyl)amine via Amine Exchange Reaction
}

\author{
Chan Sik Cho, ${ }^{*}{ }^{\dagger}$ Dong Tak Kim, Tae-Jeong Kim, and Sang Chul Shim* \\ 'Research Institute of Indtustrial Technology: Kintngpook Kational Chiversity, Daegu 702-701, Korea \\ Department of Industrial Chemistry, College of Engineering, Kinthgook Kational University, Daegu 702-701, Korea \\ Received April 8, 2003
}

Key Words : Anilines. Tris(3-hyddroxypropyl)amine. $C_{3}$-Fragment. Quinolines. Ruthenium catalyst

It is known that transition metal-catalyzed alkyl group transfer between alkylamines (anine exchange reaction or anine scrambling reaction) has been used for the synthesis of unsymmetrical anines and N-heterocycles and for the study of the metabolism of amines. ${ }^{1}$ During the course of our ongoing studies on homogeneous ruthenium catalysis, ${ }^{2.6}$ we have directed our attention to the alkyl group transfer from $\alpha$-hydrogen containing amines to the $\mathrm{N}$-atom of anilines. which eventually leads to indoles ${ }^{2}$ and quinolines. ${ }^{3}$ However. except for our findings, cyclization reaction using such an alkyl group transfer as yet seents to be limited to only palladium-catalyzed synthesis of hydropyrimidines. inidazolidines and imidazoles. ${ }^{7}$ In relation to our rutheniumcatalyzed quinoline synthesis. several amines such as triallylamine, ${ }^{\text {sa }}$ trialkylanines. ${ }^{36.3 \mathrm{c}}$ and 3-amino-1-propanols ${ }^{3 \mathrm{~d}, 3 \mathrm{e}}$ as well as alkylammonium halides ${ }^{3 \mathrm{j} .3 \mathrm{z}}$ were used as alkyl group donors. Herein. as an another example for the synthesis of N-heterocycles using such an intrinsic alkyl group transfer, we report a ruthenium-catalyzed quinoline formation via $\mathrm{C}_{3}$-fragment transfer from tris(3-hydroxypropyl)amine ${ }^{8}$ to nitrogen atom of anilines.

Based on our previous reports for ruthenium-catalyzed synthesis of indoles and quinolines vic an amine exchange reaction. ${ }^{-3}$ some results for the rutheniun-catalyzed reaction between aniline (1a) and tris(3-hydroxypropyl)amine (2) under various conditions are listed in Table 1 . Treatment of 1 a with 2 in the presence of a cataly tic amount of $\mathrm{RuCl}_{3} n \mathrm{H}_{2} \mathrm{O}$ (5 $\mathrm{mol} \%) / \mathrm{PPh}_{3}$ (15 mol\%) along with $\mathrm{SnCl}_{2} \cdot 2 \mathrm{H}_{2} \mathrm{O}$ and acetone at $180^{\circ} \mathrm{C}$ for $24 \mathrm{~h}$ afforded quinoline (3a) in $60 \%$ yield (based on 2) (entry 1). The yield of 3a was considerably affected by the molar ratio of $[1 \mathrm{1a}] /[2]$. The best result was accomplished by the molar ratio of $[1 \mathrm{a}] /[2]=4.0$. The addition of $\mathrm{SnCl}_{2} \cdot 2 \mathrm{H}_{2} \mathrm{O}$ was essential for the formation of $3 \mathbf{a}$. When the reaction was carried out in the absence of $\mathrm{SnCl}_{2} \cdot 2 \mathrm{H}_{2} \mathrm{O}$. 3a was produced in only $5 \%$ yield (entry 2 ). Furthermore, the addition of a suitable hydrogen acceptor was necessary for the effective formation of 3a. Performing the reaction in the absence of hydrogen acceptor resulted in a lower yield of 3a when compared to the reaction in the presence of hydrogen acceptor (entries 1 and 3). Several hydrogen acceptors such as acetophenone and dodec-1-ene could be alternatively used. but the yield of $3 \mathrm{a}$ was lower than that when acetone was used (entries 4 and 5). However, performing the reaction in the presence of oct-1-yne was
Table 1. Optimization of conditions for the reaction of 1 a with $2^{a}$

\begin{tabular}{|c|c|c|c|}
\hline $1 \mathbf{a}$ & 2 & & $3 a$ \\
\hline Entry & Ruthenium catalyst & Hydrogen acceptor & Yield $(\%)^{b}$ \\
\hline 1 & $\mathrm{RuCl}_{3} n \cdot \mathrm{H}_{2} \mathrm{O} / 3 \mathrm{PPh}_{3}$ & acetone & 60 \\
\hline $2^{c}$ & $\mathrm{RuCl}_{3} n \cdot \mathrm{H}_{2} \mathrm{O} / 3 \mathrm{PPh}_{3}$ & acetone & 5 \\
\hline 3 & $\mathrm{RuCl}_{3} n \cdot \mathrm{H}_{2} \mathrm{O} / 3 \mathrm{PPh}_{3}$ & - & 35 \\
\hline 4 & $\mathrm{RuCl}_{3} n \cdot \mathrm{H}_{2} \mathrm{O} / 3 \mathrm{PPh}_{3}$ & acetophenone & 49 \\
\hline 5 & $\mathrm{RuCl}_{3} n \cdot \mathrm{H}_{2} \mathrm{O} / 3 \mathrm{PPh}_{3}$ & dodec-1-ene & 45 \\
\hline 6 & $\mathrm{RuCl}_{3} n \cdot \mathrm{H}_{2} \mathrm{O} / 3 \mathrm{PPh}_{3}$ & oct-1-yne & 26 \\
\hline 7 & $\mathrm{RuCl}_{2}\left(\mathrm{PPh}_{3}\right)_{3}$ & acetone & 33 \\
\hline 8 & $\mathrm{RuCl}_{2}(=\mathrm{CHPh})\left(\mathrm{PCl}_{3}\right)_{2}$ & acetone & 21 \\
\hline 9 & $\mathrm{Ru}_{3}(\mathrm{CO})_{12}$ & acetone & 45 \\
\hline 10 & $\mathrm{RuH}_{2}\left(\mathrm{PPh}_{3}\right)_{4}$ & acetone & 9 \\
\hline 11 & $\mathrm{Cp}^{*} \mathrm{RuCl}_{2}(\mathrm{CO})^{d}$ & acetone & 18 \\
\hline
\end{tabular}

"Reaction conditions: 1 a ( $4 \mathrm{mmol}) .2$ ( 1 mmol). hrdrogen acceptor ( 10 mmol), ruthenium catalyst $\left(0.05 \mathrm{mmol}\right.$ ), $\mathrm{SnCl}_{2}-2 \mathrm{H}_{2} \mathrm{O}$ (1 mmol), dioxane $(10 \mathrm{~mL}), 180^{\circ} \mathrm{C}$. for $24 \mathrm{~h}$. under argon. ${ }^{b} \mathrm{GLC}$ yield based on 2 . "In the absence of $\mathrm{SnCl}_{2} \cdot 2 \mathrm{H}_{2} \mathrm{O} .{ }^{d} \mathrm{Cp}^{*}=\eta^{3}-\mathrm{C}_{5} \mathrm{Me}_{5}$

ineffective and GLC analysis of crude reaction mixture showed very complicated products. which may be attributed to dimerization and trimerization of oct-1-yne under ruthenium catalyst system (entry 6). ${ }^{9}$ Among various ruthenium precursors we examined. $\mathrm{RuCl}_{3} n \mathrm{H}_{2} \mathrm{O} / 3 \mathrm{PPh}_{3}$ revealed to be the cataly st of choice (entries 7.11). As a result, the reaction condition of entry 1 in Table 1 was revealed to be optimal for obtaining $\mathbf{3 a}$.

Having established optimal reaction conditions. the reactions of various anilines $(\mathbf{1 b}-1 \mathrm{~m})$ with 2 were screened to investigate the scope of the present method (Table 2). The quinoline yield was considerably affected by the position and electronic nature of the substituent on $\mathbf{1}$. With onthosubstituted anilines, the quinoline yield was lower than that when meta- and para-substituted anilines were used (entries 2-4). Especially. the reaction with $o$-anisidine (1e) scarcely afforded product $3 \mathrm{e}$ (entry 5). It is reported by Watanabe et al that this may be due to deactivation of ruthenium catalyst by coordination of two adjacent methosy and amino substituent of $1 \mathrm{e}$ to ruthenium. ${ }^{15}$ In the case of $m$-toluidine (1c). the corresponding quinolines (3c) were obtained as a 
Table 2. Rutheniunn-catalyzed synthesis of quinolines $3^{a}$

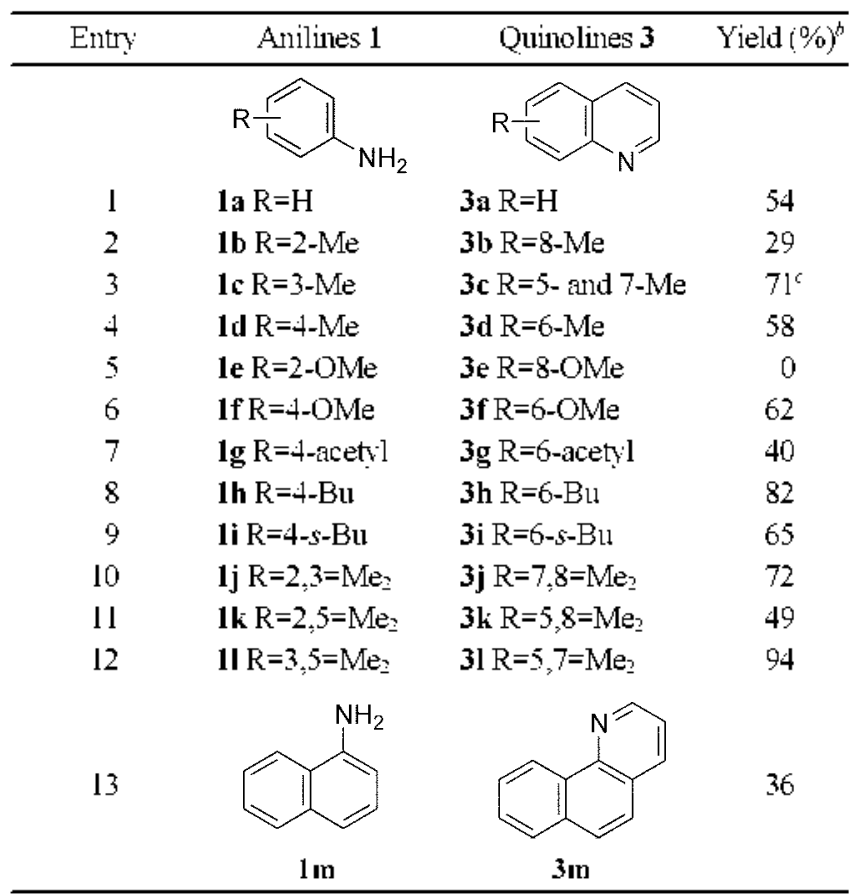

"Reaction conditions: 1 ( 4 mmol). 2 (1 mmol), acetone (lo mmol), $\mathrm{RuCl}_{3} n \mathrm{H}_{2} \mathrm{O}(0.05 \mathrm{mmol})$. $\mathrm{PPl} 2(0.15 \mathrm{mmol}), \mathrm{SnCl}_{2} \cdot 2 \mathrm{H}_{2} \mathrm{O}$ (l mmol). dioxane $(10 \mathrm{~mL}) .180^{\circ} \mathrm{C}$. for $24 \mathrm{~h}$, under argon. ${ }^{6}$ Isolated yield based on 2. 'Regioisomeric distribution was determined by ${ }^{1} \mathrm{H}$ NMR $(400 \mathrm{MHz})$ : $7-\mathrm{Me} 5-\mathrm{Me}=5: 1$

regioisomeric mixture. favoring the 7-methyl isomer which was formed via less sterically hindered position on 1c (entry 3). With 19 having electron-withdrawing acetyl substituent. the product yield was lower than that when anilines having electron-donating substituents such as alkyl and methoxy were employed (entry 7). The reaction proceeds likewise with two-methyl substituted anilines $(1 \mathbf{j}-1 \mathrm{l})$ to give the corresponding quinolines (3j-3l) in good yields (entries 10 12). The cyclization also took place with 1 -aminonaphthalene $(1 \mathrm{~m})$ to afford 7.8-benzoquinoline $(3 \mathrm{~m})$ in $36 \%$ yield (entry 13)

As to the reaction pathway. although the exact role of $\mathrm{SnCl}_{2} \cdot 2 \mathrm{H}_{2} \mathrm{O}$ is not y'et understood and no intermediates were detected at present stage. ${ }^{1]}$ this seems to proceed via a sequence involving initial propanol group transfer from 2 to $\mathrm{N}$-atom of 1a (amine exchange reaction) to form 3-anilino1-propanol (4). ${ }^{1} \mathrm{~N}$-alkylation of 1 a with 4 to form 1.3 dianilinopropane (5) (Cycle $\mathrm{A}$ in Scheme 1) ${ }^{12.13}$ and heteroannulation of 5 via orthometallation (Cycle B in Scheme 1). ${ }^{1+}$ Watanabe and Tsuji proposed the formation of $\mathbf{4}$ and $\mathbf{5}$ as intermediates on ruthenium-catalyzed șynthesis of quinolines from anilines and 1.3-diols. ${ }^{\text {lo }}$ They also confirmed in a separate experiment that 4 reacted with $1 \mathrm{a}$ in the presence of a ruthenium catalyst to give $\mathbf{3} \mathbf{a}$ and $\mathbf{5}$ was intramolecularly cyclized to give $3 a^{\text {lá }}$

In summary, we have shown that anilines react with tris(3hydroxy propyl)amine in the presence of a ruthenium cataly'st along with $\mathrm{SnCl}_{2} 2 \mathrm{H}_{2} \mathrm{O}$ and acetone to give quinolines in moderate to good yields. The present reaction is an another

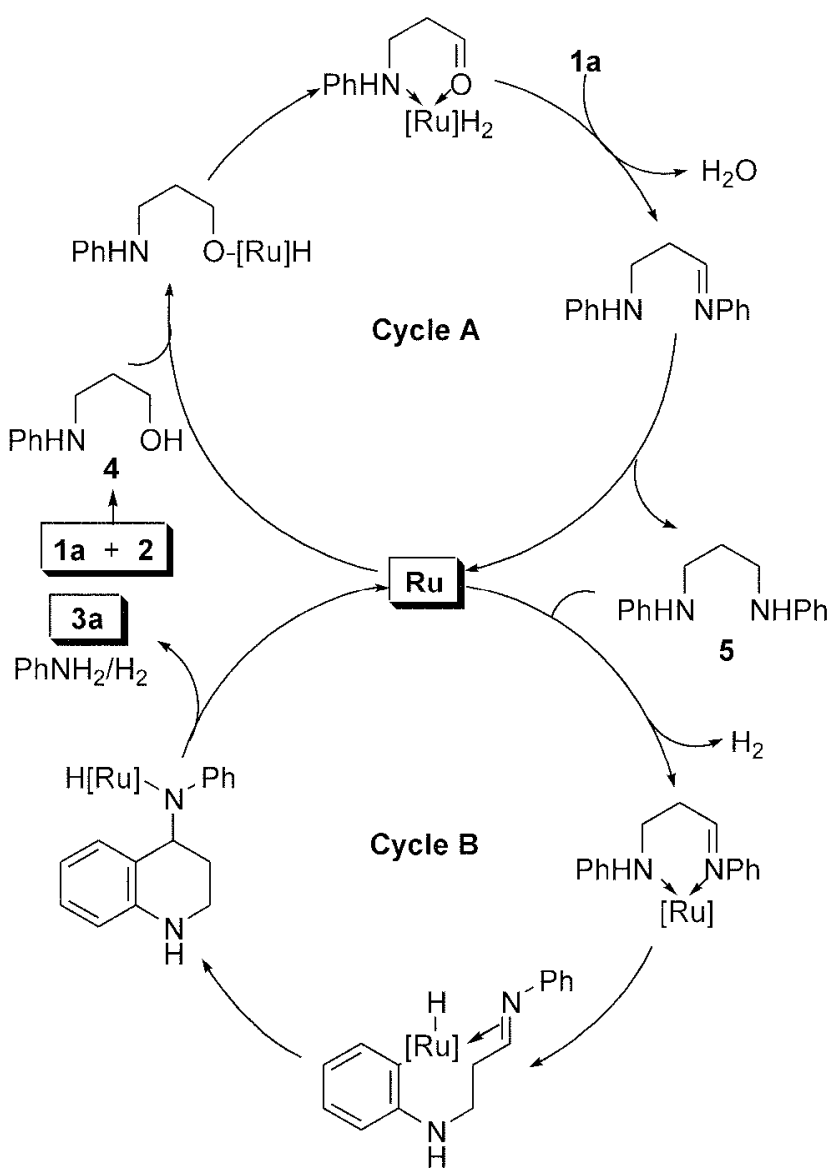

Scheme 1

approach for the synthesis of N-heterocycles using transition metal-catalyzed amine exchange reaction.

\section{Experimental Section}

General procedure for ruthenium-catalyzed reactions between 1 a and 2 for 3 a (for GLC analysis). A mixture of 1 a $(0.373 \mathrm{~g} .4 \mathrm{mmol}) .2(0.191 \mathrm{~g} .1 \mathrm{mmol})$. ruthenium cataly'st $(0.05 \mathrm{mmol})$. $\mathrm{SnCl}_{2} \cdot 2 \mathrm{H}_{2} \mathrm{O}(0-1 \mathrm{mmol})$ and hỵdrogen acceptor $(0-10 \mathrm{mmol})$ in dioxane $(10 \mathrm{~mL})$ was charged in a $50 \mathrm{~mL}$ stainless steel autoclave. After the system was flushed with argon, the resulting mixture was stirred at 180 ${ }^{\circ} \mathrm{C}$ for $24 \mathrm{~h}$. The reaction mixture was filtered through a short silica gel column (ethỵl acetate-chloroform mixture) to eliminate inorganic salts. To the extract was added appropriate amount of internal standard and analyzed by GLC.

General procedure for ruthenium-catalyzed synthesis of 3 from 1 and 2 (for isolation). A mixture of 1 (4 mmol). $2(0.191$ g. $1 \mathrm{mmol}), \mathrm{RuCl}_{2} \cdot n \mathrm{H}_{2} \mathrm{O}(0.013 \mathrm{~g} .0 .05 \mathrm{mmol})$. $\mathrm{PPh}_{3}(0.039 \mathrm{~g} .0 .15 \mathrm{mmol}), \mathrm{SnCl}_{2} \cdot 2 \mathrm{H}_{2} \mathrm{O}(0.226 \mathrm{g.} 1 \mathrm{mmol})$ and acetone $(0.730 \mathrm{~mL}, 10 \mathrm{mmol})$ in dioxane $(10 \mathrm{~mL})$ was charged in a $50 \mathrm{~mL}$ stainless steel autoclave. After the system was flushed with argon. the reaction mixture was allowed to react at $180^{\circ} \mathrm{C}$ for $24 \mathrm{~h}$. The reaction mixture was filtered through a short silica gel column (ethỵl acetatechloroform mixture) to remove inorganic compounds and 
concentrated under reduced pressure. The residual mixture was separated by TLC to give the product quinoline. All products prepared by the above procedure are hlown

Acknowledgement. This work was supported by Korea Research Foundation Grant (KRF-2002-005-C00009). C.S.C. gratefully acknowledges a MOE-KRF Research Professor Progrant (KRF-2001-050-D00015).

\section{References and Notes}

1. For anine exchange reaction catalyzed by transition metals such as Ru. Os. Co. Rh. Ir. and Pd. see: (a) Yoshimura. N.: Moritani. I.: Shimamura. T.: Murahashi. S.-I. J. An. Chem. Soc. 1973. 95. 3038. (b) Murahashi. S.-I.: Hirano. T: Yano. T. J. Am. Chem. Soc. 1978, 100, 348. (c) Shvo, Y: Laine, R. M. J. Chem. Soc., Chem. Commm. 1980. 753. (d) Khai. B.-T.: Concilio, C : Porzi. G. $J$. Organontet Chem. 1981 208, 249. (e) Khai, B-T.: Concilio. C: Porzi. G. J. Org Chem 1981. t6. 1759. (f) Arcelli. A.: Khai. B.T.: Porzi. G. J Orgunonet Chem. 1982. 231. C31. (g) Murahashi. S.-I.: Kondo. K.: Hakata. T. Tetrahedron Lett. 1982. 23. 229. (h) Laine, R. M.: Thomas, D. W. Cary. L. W. $J$. Am. Chem. Soc. 1982, 104. 1763. (i) Jung, C. W: Fellnan11, I. D: Garou, P. E. Organontallics 1983,2. 1042. (j) Murahashi, S.-I. Angen: Chem, Int Ed. 1995 .34.2443.

2. (a) Cho. C. S.: Lim. H. K.: Shim. S. C.: Kim. T.-J: Choi. H.-J. Chem. Commm. 1998. 995. (b) Cho. C. S.: Kim. J. H.: Shim. S. C. Tetrahedron Lett. 2000, H. 1811 . (c) Cho, C. S: Kim, J. H.: Kim. T.-J.: Shim. S. C. Tetratretron 2001, 57. 3321. (d) Cho, C. S.: Kim. T.-K.: Yoon, S. W.: Kin, T.-T.: Shim. S. C. Bull. Korean Chem. Soc. 2001.22.545.

3. (a) Cho. C. S.: Oh. B. H.: Shim. S. C. Tetrahedron Lett 1999. to. 1499. (b) Cho. C. S.: Oh. B. H.: Kim. J. S.: Kim. T.-J.: Shim. S. C. Chem. Commm, 2000, 1885. (c) Cho. C. S: Kim, T. K.: Kim. B. T: Kim. T.-J: Shim. S. C.J. Organomet. Chem 2002. 650,65. (d) Cho, C. S: Oh. B. H: Shim. S. C. J. Heterocuct Chem. 1999, 36 1175. (e) Cho. C. S.: Kim. T.-K.: Kim. T.-J.: Shim. S. C.: Yoon. N. S. J. Heterockd Chent 2002. 39. 291. (f) Cho. C. S.: Kim. J. S.: Oh. B. H.: Kim. T.-J.: Shim. S. C.: Yoon. N. S. Tetrahedron 2000. 56, 7747. (g) Cho. C. S: Kim. T. K: Choi. H.J Kim. T.-T.: Shim. S. C. Bull Korean Chem. Soc, 2002. 23, 541 .

4. (a) Cho. C. S.: Kim. B. T: Kim. T.-I.: Shim. S. C.J. Org Chem.
2001. 66,9020. (b) Cho, C. S.; Kim, B. T.: Kim, T.-J; Shim. S. C. Chent Commm 2001. 2576. (c) Cho. C. S.: Kim. B. T.: Kim. T.J.: Shim. S. C. Tetrahedron Lett. 2012. +3. 7987.

5. Cho. C. S.: Kiml. B. T.: Lee. M. J.: Kiml. T.-J.: Shim. S. C. Angew. Chem. Int Ed. $2001,40.958$.

6. Cho. C. S.: Kim. J. H.; Choi. H.-J; Kim, T.J.: Shim, S. C. Tetrahedron Lett. 2003, H. 2975

7. Murahashi. S.-I.: Yoshimura. N.: Tsumiyama. T.: Kojima. T. $J$. Ant Chent Soc. 1983. 105.5002.

8. Renaud. F.: Decurnex. C.: Piguet. C.: Hoptgartner. G. J. Chem Soc, Dalon Trans. 2001, 1863

9. (a) Naota, T; Takava, H.: Murahashi, S.-I. Chem. Rkw 1998.98. 2599. (b) Y. C. S.: Liu. N. Sintett 1999, 281.

10. Tsuiji. Y: Nishimura. H.: Huh. K.-T.: Watanabe. Y. J. Orgomontet. Chent 1985. 286. C44. (b) Tsuji. Y.: Huh. K.-T.: Watanabe. Y. J. Org. Chem. 1987.52. 1673

11. For catalytic activity of transition metal-tin complexes. see: Holts. M. S.; Wilson, W. L.: Nelson. J. H. Chem Rev 1989.89. 11.

12. It is well known that amines react with primary alcohols in the presence of a ruthenium catalyst to give N-alhylated amines ria a sequence involving oxidation. condensation. and reduction. For transition metal-catalyzed N-alkylation of amines by alcohols. see: (a) Rice. R. G.; Kohn. E. J. J. Am. Chem Soc. 1955. 77, 4052. (b) Murahashi. S.I.; Shimamura, T; Moritani, I. J. Chem. Soc.. Chent Commm. 1974, 931. (c) Baiker. A.; Richarz, W. Tetrahedon Lett. 1977. 1937. (d) Grigg. R.: Mitchell. T. R. B.: Sutthivaiyakit. S.: Tongpenyai. N. J. Chem. Soc. Chent Conmum. 1981. 611. (e) Watanabe. Y: Tsuji. Y.: Ohsugi. Y. Tetrahadron Lett. 1981, 22. 2667. (f) Arcelli, A.; Khai, B.-T.: Porzi, G. $J$. Organonet. Chem. 1982, 235, 93. (g) Watanabe. Y: Tsuji, Y. Ohsugi. Y.: Shida, J. Bull. Chent. Soc. Jpm. 1983. 56, 2452. (h) Watanabe. Y.: Isuji. Y.: Ige. H.: Ohsugi. Y.: Ohta. T. J. Org. Chent 1984. 19. 3359. (i) Tsuji. Y.: Takeuchi. R.: Ogawa. H.: Watanabe. Y. Chem. Lett. 1986. 293. (j) Vultier. R.: Baiker. A.: Wokaun. A. Appl. Catal. 1987, 30, 167. (k) Bitsi. G.; Jenner. G. J. Organomet. Chem. 1987. 330. 429. (I) Marsella, J. A. J. Org. Chem. 1987. 52. 467. (m) Huh. K.-T.: Tsuji. Y: Kohayashi, M: Okuda, F.: Watanale. Y. Chent Lett 1988. 449. (n) Ganguly. S.: Toslin. F. L.: Roundhill. D. M. Inorg. Chem. 1989. 28.4562. (o) Watanabe. Y.: Morisaki. Y.: Kondo. T.: Mitsudo. T. J. Org. Chem. 1996. 61. 4214.

13. Kim. G.; Lee, D. G.: Chang. S. Bull. Korean Chem. Soc. $2001,22$. 943.

14. Omae. I. Chem. Rev 1979. 79. 287 